\title{
Pengembangan Usaha Minyak Kelapa Tradisional untuk Meningkatkan Pendapatan IKM Desa Posso, Kabupaten Gorontalo Utara
}

\section{(Development of Traditional Coconut Oil to Increase Income of SMEs in Posso Village, North Gorontalo District)}

\author{
Rosdiani Azis ${ }^{1 *}$, Ingka Rizkyani Akolo', Mohammad Fikri Pomalingo ${ }^{2}$, Ikrima Staddal ${ }^{3}$ \\ 1 Program Studi Teknologi Hasil Pertanian, Politeknik Gorontalo, Desa Panggulo, JL. Saptamarga, Bone Bolango, \\ Kabupaten Bone Bolango, Gorontalo 96112 \\ 2 Program Studi Teknologi Mesin Pertanian, Universitas Negeri Manado, Jl. Raya Tondano, Koya, Tondano Selatan, \\ Kabupaten Minahasa, Sulawesi Utara 95618. \\ 3 Program Studi Mesin Peralatan Pertanian, Politeknik Gorontalo, Desa Panggulo, JL. Saptamarga, Bone Bolango, \\ Kabupaten Bone Bolango, Gorontalo 96112. \\ *Penulis Korespondensi: rosdiani@poligon.ac.id \\ Diterima September 2019/Disetujui Januari 2020
}

\begin{abstract}
ABSTRAK
Desa Posso merupakan salah satu desa yang berada di Kecamatan Kwandang, Kabupaten Gorontalo Utara, Provinsi Gorontalo. Desa Posso memiliki potensi perkebunan kelapa dengan kapasitas produksi 15.000 butir/ bulan. Dalam rangka untuk meningkatkan potensi desa dan nilai tambah produk kelapa, dilakukan pengembangan Industri Kecil Menengah (IKM) yang menghasilkan produk minyak kelapa. Tujuan kegiatan ini adalah untuk mengembangkan usaha minyak kelapa tradisional untuk meningkatkan pendapatan IKM. Tahapan kegiatan pengembangan usaha minyak kelapa meliputi: alih teknologi, penyediaan alat, penerapan teknologi, dan pendampingan produksi. Berdasarkan hasil kegiatan diperoleh hasil pelatihan desain kemasan dan proses pengemasan yang baik dan benar serta manajemen usaha dapat meningkatkan keterampilan mitra dalam mendesain kemasan yang menarik dan mampu mengelola usaha ini. Setelah kegiatan pengembangan usaha minyak kelapa ini, dihasilkan pengetahuan tentang metode fermentasi dalam pembuatan minyak, pengetahuan tentang cara pengoperasian alat pengupas sabut dengan metode cakar ayam, pengetahuan dalam manajemen usaha pengolahan minyak kelapa tradisional, serta peningkatan aset mitra di mana dalam sebulan produksi minyak meningkat menjadi $150 \mathrm{~L}$ atau sekitar 200 botol. Secara keseluruhan program ini terlaksana dengan baik dan bermanfaat bagi pihak IKM khususnya dalam pengembangan usaha IKM sukses bersama.
\end{abstract}

Kata kunci: IKM, kelapa, minyak, pengembangan

\begin{abstract}
Posso is one of the villages which is located in Kwandang sub-district, North Gorontalo District, Province of Gorontalo. It has the potential of coconut plantations with a production capacity of around15,000 coconuts/month. In order to increase the potential of village, the government formed a jointly successful SMEs that are produces traditional coconut oil. The purpose of this activity is to develop a traditional coconut oil business to increase SMEs incomes. The method applied are technology transfer, provision of tools, application of technology and production assistance. Based on the results showed activities obtained training results of packaging design and packaging process that is good and proper and business management can improve partners' skills in designing attractive packaging and able to manage this business. After this coconut oil business development's activity, it produced knowledge about the fermentation method in making oil, how to operate coir peeling tools with a chicken paw method, management of a traditional coconut oil processing business, and an increase in partner assets which oil production increased to $150 \mathrm{~L}$ or around 200 bottles per month. Overall, this program is well implemented and has benefits for SMEs, especially in developing a successful SME business together.
\end{abstract}

Keywords: coconut oil, development, SMEs

\section{PENDAHULUAN}

Desa Posso adalah salah satu Desa yang berada di Kecamatan Kwandang, Kabupaten Gorontalo Utara, Provinsi Gorontalo. Jarak desa ini dari kampus Politeknik Gorontalo adalah sekitar $62 \mathrm{~km}$. Secara geografis Desa Posso memiliki luas sekitar 3.600 ha yang terbagi dalam beberapa jenis lahan. Lahan datar dihuni oleh masyarakat dan perkebunan kelapa, lahan hutan 
produksi, dan lahan tidak produktif. Desa Posso merupakan desa penghasil kelapa terbesar di Kabupaten Gorontalo Utara. Potensi kelapa di Desa ini mencapai 15.000 butir/bulan (BPS 2016). Potensi kelapa ini sangat besar dan layak untuk dapat ditingkatkan nilai tambah dan daya saingnya.

Pengoptimalan potensi desa dan peningkatan pendapatan masyarakat Desa Posso, Kecamatan Kwandang, Kabupaten Gorontalo Utara, diupayakan pemerintah desa melalui Badan Usaha Milik Desa (Bumdes) membentuk kelompok Industri Kecil Menengah (IKM) yang berkecimpung pada program pembuatan minyak kelapa tradisional. IKM ini sebagian besar beranggotakan ibu-ibu rumah tangga (kalangan muda dan lansia) dan bapak-bapak pengepul (pengumpul) kelapa. IKM ini diharapkan dapat memberdayakan masyarakat Desa khususnya ibu-ibu rumah tangga (istri petani) agar mempunyai pekerjaan sampingan yang dapat menjadi potensi pendapatan yang signifikan bagi kesejahteraan hidupnya.

Menurut hasil survei tim pengabdian Politeknik Gorontalo, teridentifikasi beberapa kendala yang dihadapi oleh IKM Sukses Bersama untuk berkembang di antaranya 1) Peralatan pengupas kelapa yang digunakan masih sangat tradisional (pasundi/luweng); 2) Cara pembuatan minyak kelapa yang tradisional, yakni menggunakan metode pemasakan santan selama 4-5 jam sampai diperoleh minyak kelapa; 3) Kemasan produk yang tidak menarik (jerigen ukuran $5 \mathrm{~L}$ ); 4) Belum ada uji laboratorium tentang komposisi kimia minyak kelapa; dan 5) Pemasaran yang belum maksimal.

Berdasarkan identifikasi permasalahan tersebut, dilakukan kegiatan pengabdian kepada masyarakat dengan tujuan untuk mengembangkan usaha minyak kelapa tradisional sehingga dapat meningkatkan pendapatan IKM. Pengembangan usaha dalam konteks ini difokuskan pada peningkatan mutu produk dan kapasitas produksi serta pendapatan IKM.

\section{METODE PELAKSANAAN KEGIATAN}

\section{Waktu dan Lokasi}

Kegiatan ini dilaksanakan selama 5 bulan, yaitu bulan April-Agustus 2019. Kegiatan pengabdian dilaksanakan di rumah produksi IKM Sukses Bersama Desa Posso, Kecamatan Kwandang, Kabupaten Gorontalo Utara. Pembuatan mesin pengupas sabut kelapa dilakukan di laboratorium Mesin Produksi Politeknik Gorontalo, dan analisa komposisi kimia minyak kelapa tradisional dilakukan di Laboratorium Sucofindo Cabang Cibitung.

\section{Tahapan Pelaksanaan Kegiatan}

Tahapan Pelaksanaan kegiatan meliputi: 1) Pelatihan mengenai teori dan praktik mengenai penggunaan mesin pengupas sabut kelapa dan pembuatan minyak kelapa; 2) Alih teknologi tentang penggunaan mesin pengupas dan pembuatan minyak kelapa dengan metode fermentasi; 3) Penerapan teknologi dan pendamping produksi serta pengujian komposisi kimia minyak kelapa tradisional; 4) Pelatihan pengemasan produk yang baik dan benar; dan 5) Pelatihan manajemen usaha dan pemasaran. Pelaksanaan kegiatan dilaksanakan secara bertahap dengan maksud agar proses alih ilmu pengetahuan dan teknologi dari tim pengabdi Politeknik Gorontalo (Poligon) kepada IKM lebih gampang dan mudah dipahami.

Tahap pertama adalah penjelasan tentang mesin pengupas sabut kelapa dan teori pengolahan minyak kelapa dengan metode fermentasi. Penjelasan mesin pengupas tipe cakar ayam meliputi: cara kerja, cara pemeliharaan, dan halhal yang menyangkut keselamatan alat serta pelaksanaan di lapangan. Pesertanya berasal dari pihak pemerintah, IKM Sukses Bersama dan aparat desa.

Tahap kedua adalah alih teknologi dan praktik langsung pengoperasian mesin pengupas kelapa dengan bimbingan dan pendampingan oleh tim pengabdi Poligon. Setiap peserta langsung mencoba mengoperasikan alat tersebut dan bila ada kekurangan atau kekeliruan maka akan langsung dijelaskan oleh pengabdi Poligon. Setelah dilakukan pengoperasian alat pengupas kelapa, selanjutnya kelapa yang sudah dikupas tadi akan dibuat minyak kelapa dengan metode fermentasi. Tim pemateri menyiapkan modul pelatihan pembuatan minyak kelapa untuk mempermudah pelatihan.

Tahap ketiga penerapan teknologi, pendampingan produksi dan pengujian laboratorium. Uji coba produksi minyak kelapa pada tahap sebelumnya kemudian diaplikasikan sehingga diperoleh minyak kelapa tradisional yang mutunya lebih baik. Analisa kualitas minyak kelapa dilakukan di laboratorium sesuai parameter Standar Nasional Indonesia (SNI). SNI minyak kelapa 01-2902-1992 meliputi kadar air, kadar kotoran, bilangan iod, bilangan peroksida, bilangan penyabunan, dan asam lemak bebas 
(BSN 1992). Sampel yang dibuat oleh pihak IKM kemudian dikirim ke Laboratorium Sucofindo untuk dilakukan pengujian.

Tahap keempat adalah pelatihan desain kemasan dan pengemasan produk. Pada tahapan ini akan diberikan perjelasan kepada pihak IKM tentang bagaimana proses pengemasan yang baik sehingga dapat mempertahankan umur simpan. Kegiatan ini dilakukan dalam bentuk sosialisasi secara langsung disertai pendampingan di lapangan sehingga pihak IKM dapat melakukan proses pengemasan dengan baik dan benar.

Tahap kelima adalah manajemen usaha dan pemasaran. Penyuluhan pengelolaan usaha dilakukan untuk mengatasi masalah manajemen usaha sehingga dapat memberikan keuntungan. Materi disusun dalam bentuk power point yang disertai gambar-gambar yang mudah dipahami dan didukung dengan penyampaian materi dalam bahasa setempat (Bahasa Gorontalo) untuk memudahkan pemahaman peserta. Pada tahap ini diundang mitra yang menjelaskan tentang manajemen usaha, strategi, dan bentukbentuk pemasaran.

\section{Metode Pengolahan Data}

Data yang berkaitan dengan kualitas minyak kelapa diperoleh dari hasil pengujian laboratorium dengan parameter kadar air, kadar kotoran, bilangan iod, bilangan peroksida, bilangan penyabunan, dan asam lemak bebas. Data yang diperoleh dianalisis secara deskriptif kualitatif.

\section{HASIL DAN PEMBAHASAN}

\section{Pengadaan Mesin Pengupas Kelapa}

Salah satu permasalahan IKM adalah peralatan yang digunakan oleh masyarakat Desa Posso masih sangat tradisional, pekerjaan masih menggunakan pasundi (luweng) untuk mengupas sabut kelapa. Penggunaan pasundi ini sangat berbahaya jika pekerjanya terutama ibu-ibu salah menancapkan kelapa pada ujung pasundi. Kesalahan tersebut dapat berakibat fatal yang membuat tangan terluka.

Upaya yang dilakukan tim PKM adalah merancang mesin pengupas sabut kelapa dengan tipe cakar ayam. Penggunaan mesin dalam pengupasan sabut sangat efektif (Alridho et al. 2018). Mesin ini dirancang sedemikian rupa untuk membantu mitra dalam mengupas kelapa. Mesin ini memiliki dimensi panjang $100 \mathrm{~cm}$, lebar $55 \mathrm{~cm}$, dan tinggi $90 \mathrm{~cm}$. Jenis penggerak yang digunakan adalah motor bakar 5,5 hp. Mesin ini dilengkapi dengan dua poros pengupas yang dilengkapi dengan mata pisau yang berbentuk seperti cakar ayam. Tipe cakar ayam diyakini akan mempercepat pengupasan dibanding tipe mata pisau lain yang ada di pasaran. Kapasitas kerja mesin ini mencapai 14 detik/butir dengan atau sekitar 2.057 butir/hari. Kapasitas ini lebih banyak dari penggunaan alat tradisional yang hanya mampu menghasilkan 1.100 butir/hari. Jumlah jam kerja yang digunakan adalah 8 jam/hari seperti yang dilakukan oleh operator yang menggunakan peralatan tradisional, yaitu luweng. Ukuran panjang mata pisau pengupas yang ideal dalam merancang mesin pengupas sabut kelapa adalah 1,5 cm dan 0,5 cm. Untuk mengurangi putaran poros, maka digunakan gearbox 1:30. Sistem transmisi yang digunakan adalah: 1) puli dan V-belt, 2) gear dan gear, dan 3) gear dan rantai. Prototipe mesin pengupas sabut kelapa tipe cakar ayam ditampilkan pada Gambar 1.

Mesin pengupas sabut kelapa yang sudah dibuat, selanjutnya disosialisasikan dan dilakukan pelatihan penggunaan mesinnya. Kegiatan ini dilakukan selama satu hari sejak pukul 08.0016.00 WITA pada 19 Juni 2019. Agar mempermudah kegiatan pelatihan, tim telah membuat buku panduan penggunaan mesin tersebut (Gambar 2). Mitra yang dilibatkan dalam pelatihan ini adalah para pria. mitra diberi pengetahuan secara spesifik terhadap cara penggunaan mesin serta sistem K3 yang ada pada mesin. Hal ini dimaksudkan agar aman dalam penggunaanya.

Tim terlebih dahulu mempraktikkan cara penggunaan mesin pengupas sabut kelapa untuk mempermudah transfer teknologi. Kegiatan tersebut dimulai dari proses menjalankan mesin hingga pengupasan kelapa sebanyak lima butir.

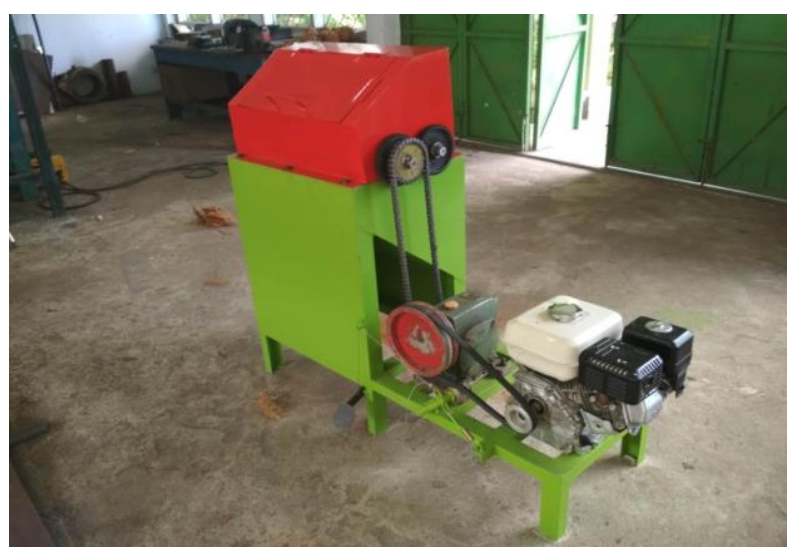

Gambar 1 Prototipe mesin pengupas sabut kelapa tipe cakar ayam. 


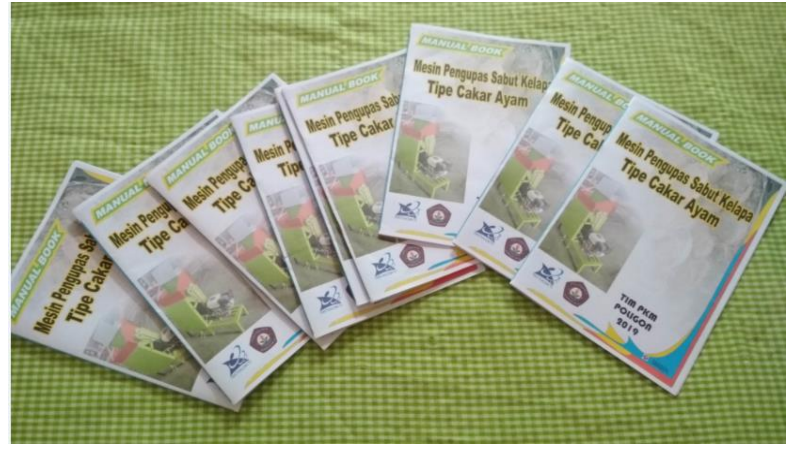

Gambar 2 Manual book penggunaan mesin.

Pada saat proses pengupasan berlangsung, tim pengabdi sebanyak tiga orang dosen yang ditemani oleh lima orang mahasiswa menjelaskan cara peletakkan buah kelapa, posisi berdiri saat pengupasan dan keselamatan kerja. Pelatihan ini diikuti oleh 12 orang. Berdasarkan hasil praktik tersebut, mitra mengerti cara penggunaan mesin dengan cepat. Hal tersebut ditandai oleh beberapa faktor, yaitu tiga orang anggota IKM Sukses bersama yang bertugas sebagai operator mesin mampu mengupas kelapa dengan baik dan bagian-bagian mesin telah mereka kuasai, hafal nama dan fungsinya, serta posisi berdiri yang merupakan aspek keselamatan kerja telah mereka kuasai.

Pelatihan penggunaan mesin yang dilakukan, mampu diterima dengan baik oleh mitra. Hal itu diperlihatkan dengan pemahaman mitra dalam pengoperasian mesin. Tim pengabdi hanya memberikan contoh dengan melakukan pengupasan 2 butir kelapa. Kriteria efektivitas yang dimaksudkan oleh tim yaitu; 1) Posisi berdiri mitra dalam mengoperasikan mesin telah sesuai seperti yang diajarkan, 2) Posisi tangan yang memegang kelapa dan penempatan posisi kelapa pada poros pengupas yang telah sesuai; dan 3) Waktu pengupasan yang dihasilkan telah mencapai 14 detik/butir sesuai dengan yang diharapkan. Waktu yang direncakan, diukur oleh tim dengan menggunakan stopwatch pada saat mitra melakukan pengupasan.

\section{Pengolahan Minyak Kelapa dengan Metode Fermentasi}

Proses pengolahan minyak kelapa yang masih menggunakan cara pemasakan tradisional yaitu proses pemanasan dengan suhu diatas $100^{\circ} \mathrm{C}$ dengan lama pemanasan 5-7 jam. Tujuan dari pemanasan untuk menghilangkan kandungan air yang terdapat di dalam santan kelapa. Umumnya minyak yang dihasilkan dengan cara pemanasan ini berwarna kekuning-kuningan. Blondo yang diperoleh dari hasil pengolahan minyak kelapa dengan cara pemanasan memiliki warna cokelat kehitaman dan ternyata menghasilkan minyak dengan rendemen yang rendah, yakni sekitar $50 \%$ dari lemak yang dikandung, serta minyak yang mudah tengik (Hawin 2010). Oleh karena itu, melalui program ini tim memandang perlu adanya pengarahan cara pembuatan minyak kelapa yang lebih baik karena selain menghasilkan minyak kelapa yang lebih tahan lama, proses pembuatannya juga tidak banyak menguras tenaga jika dibandingkan dengan cara pemanasan.

Proses pengolahan minyak kelapa yang tim tawarkan adalah metode fermentasi. Keunggulan teknik fermentasi adalah waktu yang digunakan saat pemanasan relatif lebih cepat, minyak yang dihasilkan akan lebih banyak dan tahan lama, serta tidak mudah tengik (Soeka et al. 2008). Metode ini dilakukan hanyalah sebagai opsi dari metode lain yang mereka gunakan, yakni metode pemasakan. Pembuatan minyak kelapa dengan metode fermentasi dilakukan dengan cara: santan yang dihasilkan dari kelapa yang sudah diparut, kemudian didiamkan selama minimal 6 jam untuk memisahkan krim santan dengan air. Selanjutnya krim difermentasi dengan bantuan enzim papain untuk memudahkan penggumpalan bagian bukan minyak (terutama protein) dari minyak pada waktu pemanasan. Mikroba yang berkembang selama fermentasi, terutama mikroba penghasil asam. Asam yang dihasilkan menyebabkan protein santan mengalami penggumpalan dan mudah dipisahkan pada saat pemanasan (Andaka \& Karomatul 2017). Proses pengolahan perlu dielaborasi lagi. Pada penelitian ini yang digunakan adalah fermentasi dan dilanjutkan dengan pemanasan. Perlu dijelaskan lagi sehingga tidak membingungkan.

Praktik pengolahan minyak dengan metode fermentasi ternyata memudahkan pihak mitra terutama ibu-ibu yang bertugas di bagian pengolahan. Sebelum menggunakan metode fermentasi, waktu yang dibutuhkan untuk memasak santan sampai menjadi minyak adalah 5-7 jam. Setelah menggunakan metode fermentasi waktu pemasakan santan menjadi minyak menjadi lebih efisien yakni tinggal 1 jam saja. Biasanya untuk untuk menghasikan 1 L minyak kelapa dibutuhkan sekitar 7-8 butir kelapa, sedangkan dengan metode fermentasi untuk menghasikan 1 L minyak hanya dibutuhkan 5-6 butir kelapa, dengan kata lain minyak kelapa yang dihasilkan dengan metode fermentasi menghasilkan rendemen yang lebih banyak dibandingkan dengan minyak kelapa yang diolah dengan cara 
tradisional. Selain itu, minyak yang dihasilkan juga lebih jernih dan mempunyai bau minyak kelapa yang khas. Hasil ini mendapatkan apresiasi dari pihak mitra karena salah satu permasalahan yang sering mereka hadapi pada pengolahan minyak kelapa bisa diselesaikan dan prosesnya menjadi lebih mudah. Pelatihan dan pendampingan metode fermentasi ini memberikan pengetahuan tambahan kepada mitra untuk menghasilkan minyak dengan kualitas yang baik. Produksi minyak kelapa yang dihasilkan mitra IKM dalam satu bulan meningkat, yaitu sebelumnya mereka menghasilkan $60 \mathrm{~L} /$ bulan setelah program ini berlangsung maka terjadi peningkatan produksi, yakni menjadi $200 \mathrm{~L} /$ bulan.

Setelah melakukan praktik secara bersama, tim pengabdi memberikan tugas kepada mitra untuk membuat sendiri tanpa arahan dari tim. Hasil dari percobaan mandiri tersebut, menunjukkan konsistensi dari kejernihan dan aroma khas minyak kelapa yang dihasilkan yang sama dengan hasil pada saat praktik bersama. Warna minyak kelapa yang dihasilkan lebih terang dibandingkan warna minyak yang biasa diproduksi oleh IKM Sukses Bersama. Aktivitas pembuatan minyak kelapa ditampilkan pada Gambar 3. Pelatihan pembuatan minyak kelapa

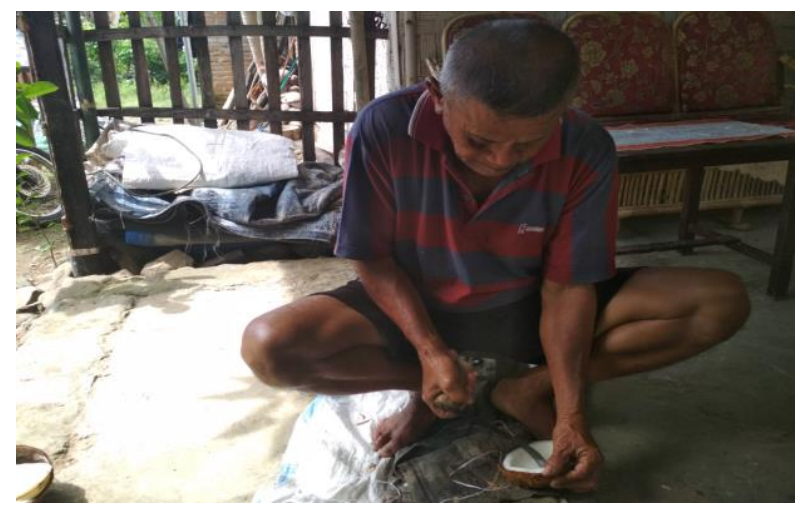

a

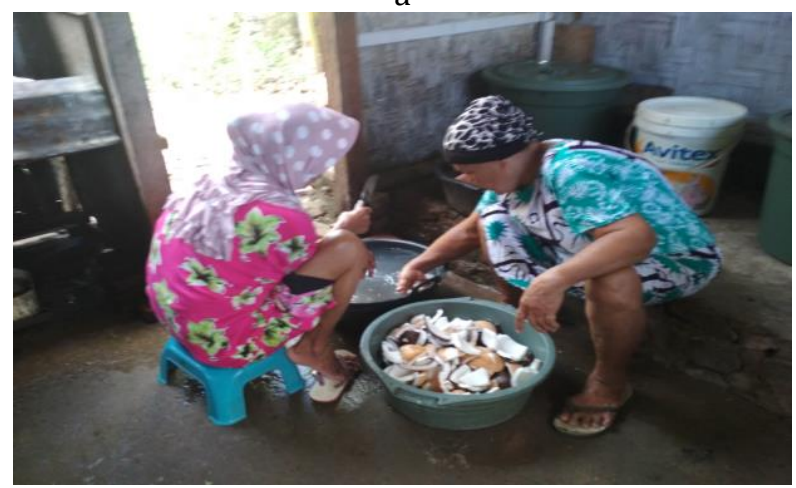

C dengan metode fermentasi membuat mitra sangat terbantu, pada umumnya langkah pembuatannya sama seperti yang biasa mereka lakukan, namun perbedaannya hanya terdapat pada proses penambahan enzim papain. Enzim papain berasa dari getah pepaya mentah dijadikan bahan tambahan karena ketersediaan yang melimpah di desa tersebut sehingga mudah didapatkan. Berdasarkan hal tersebut, tim beranggapan bahwa mitra mampu menguasai materi yang diberikan dengan cepat dan baik.

Selama ini mitra menggunakan pemanasan suhu tinggi padahal hal ini membuat produk minyak cepat rusak, hal ini sesuai dengan pendapat (Raharja \& Dwiyuni 2010) bahwa pemanasan di atas $100^{\circ} \mathrm{C}$ pada proses ini yang menyebabkan perubahan secara kimia dari asam lemak tak jenuh serta merusak antioksidan alami yang ada pada kelapa sehingga dapat dikatakan bahwa pemanasan yang tinggi pada cara tradisional dapat mengubah struktur minyak dan menghasilkan warna minyak kurang baik, serta menyebabkan minyak mudah tengik. Sementara untuk metode fermentasi menurut (Soeka et al. 2008). Kelebihan ekstraksi minyak kelapa dengan fermentasi adalah praktis, hemat energi, residu (galendo) yang rendah, bilangan asam rendah, serta bebas senyawa penginduksi

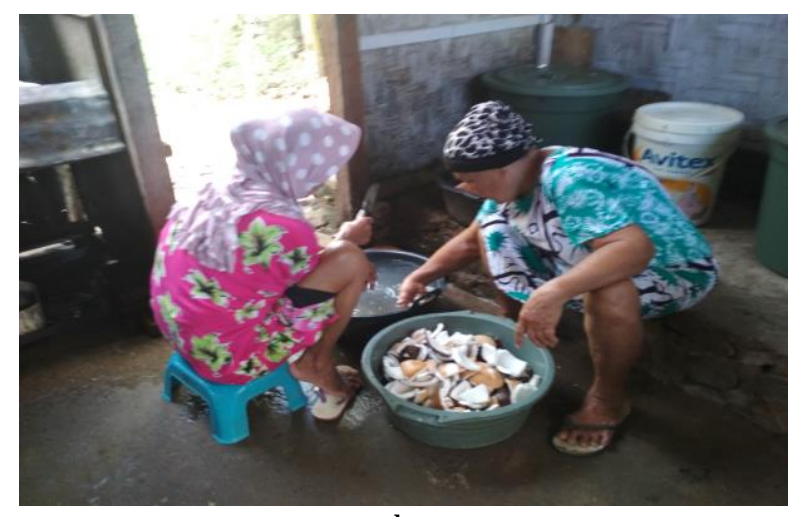

b

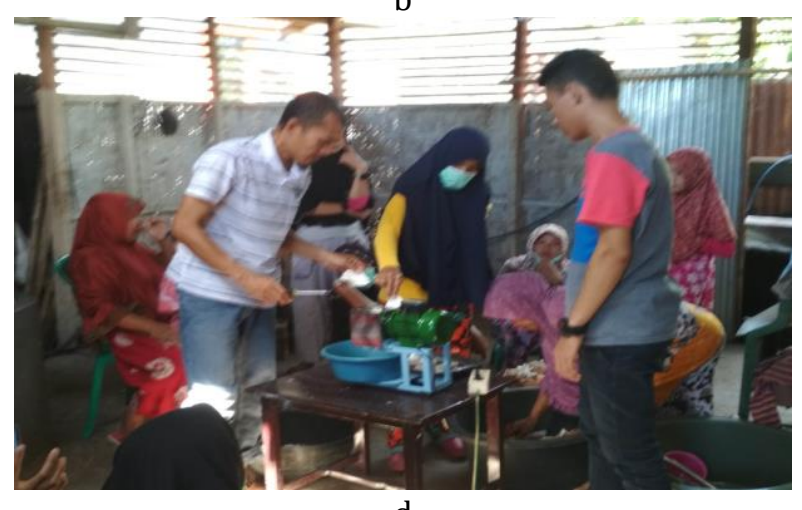

d

Gambar 3 Tahapan proses pembuatan santan: a) Pelepasan daging kelapa dari batok; b) Pencucian, c) Pemarutan kelapa; dan d) Pembuatan santan. 
kolesterol. Penggunaan metode fermentasi merubah beberapa ciri khas dari produk mitra, tetapi masih memenuhi standar SNI minyak kelapa tradisional SNI 7381 (BSN 2008), yaitu minyak kelapa yang dihasilkan dengan metode fermentasi memiliki warna yang lebih terang dan bau khas minyak kelapa tradisional hilang. Terkait dengan warna, mitra tidak mempermasalahkan hal tersebut. Permasalahan utamanya adalah pada bau minyak yang khas. Minyak kelapa tradisional memiliki bau yang khas, hal ini menjadi parameter setiap orang Gorontalo dalam menilai kualitas minyak. IKM Sukses Bersama ingin mempertahankan bau khas minyak kelapa yang merupakan turunan dari resep leluhur mereka. Menurut Maman, yang merupakan salah satu anggota mitra, bau khas minyak dihasilkan dari asap yang berasal dari bahan bakar pada proses pemanasan. Pemanasan menggunakan bahan bakar sabut kelapa dianggap dapat memberikan bau khas tersebut.

\section{Hasil Uji Laboratorium}

Pengujian laboratorium terhadap produk minyak kelapa sangat dibutuhkan oleh mitra untuk memenuhi kualitas minyak kelapa sesuai SNI. Pada dasarnya mereka belum memahami akan kebutuhannya. Tim memberikan pemahaman terhadap hasil pengujian laboratorium.

Adapun hasil Analisa Minyak kelapa yang diproduksi oleh IKM Sukses Bersama ditunjukkan pada Tabel 1. Dari hasil uji tersebut menunjukkan bahwa kualitas minyak yang diolah oleh IKM Sukses Bersama memiliki kualitas terbaik. Hasil uji tersebut menunjukkan bahwa untuk bilangan iod nilainya sebesar $8,41 \mathrm{mg}$ jod/100 g contoh, sementara untuk SNI minyak kelapa bilangan iodnya sebesar 4-11 mg jod/ 100 g. Bilangan iod menjadi salah satu indikasi bahwa yang digunakan untuk menentukan ketidakjenuhan dan ketengikan minyak kelapa, makin tinggi bilangan iod makin lanjut proses ketengikan yang terjadi pada minyak kelapa. Ketengikan yang diartikan sebagai kerusakan atau perubahan bau dan rasa (flavour) dalam minyak. Pada proses pembuatan minyak pada masih berada di angka yang sesuai dengan SNI, hal ini berarti minyak kelapa ini telah memenuhi persyaratan mutu yang ditetapkan SNI.

Hasil bilangan peroksida minyak kelapa ini menunjukkan nilai nil artinya tidak terindikasi adanya peroksida, berdasarkan SNI angka peroksida minyak kelapa adalah maksimal $0,2 \mathrm{mg}$ oksigen/g contoh, dari data tersebut menunujukkan bahwa minyak kelapa tidak terindikasi
Tabel 1 Hasil analisis minyak kelapa yang diproduksi oleh Industri Kecil Menengah Sukses Bersama

\begin{tabular}{|c|c|}
\hline Karakteristik & Hasil uji \\
\hline $\begin{array}{l}\text { Bilangan Iod (mg jod/100 g } \\
\text { contoh) }\end{array}$ & 8,4 \\
\hline $\begin{array}{l}\text { Bilangan peroksida (mg } \\
\text { oksigen/g contoh) }\end{array}$ & Nil \\
\hline $\begin{array}{l}\text { Bilangan penyabunan (mg } \\
\mathrm{KOH} / \mathrm{g} \text { contoh) }\end{array}$ & 264,37 \\
\hline Asam lemak bebas & $0,17 \%$ \\
\hline Warna, bau, aroma & Normal \\
\hline Komposisi asam lemak & $\%$ \\
\hline Asam kaproat & 0,41 \\
\hline Asam kaprilat & 5,76 \\
\hline Asam kaprat & 5,13 \\
\hline Asam laurat & 45,29 \\
\hline Asam miristat & 20,18 \\
\hline Asam stearat & 3,54 \\
\hline Asam palmitat & 10,43 \\
\hline Asam oleat & 7,59 \\
\hline Asam linoleat & 1,49 \\
\hline
\end{tabular}

adanya ketengikan karena angka peroksida dalam minyak kelapa menunjukkan bahwa semakin tinggi angka peroksida maka akan lebih besar peluang minyak teroksidasi, jika terjadi oksidasi pada minyak maka akan menyebabkan cepatnya minyak mengalami ketengikan. Pada produk minyak kelapa ini lebih kecil dari SNI. Hal ini berarti minyak kelapa ini telah memenuhi persyaratan mutu yang ditetapkan SNI.

Bilangan penyabunan minyak kelapa sebesar $264.37 \mathrm{mg} \mathrm{KOH} / \mathrm{g}$ contoh, sementara standar minyak kelapa untuk bilangan penyabunan bersarkan SNI 255-265 KOH/g contoh, hal ini menunjukkan bahwa bilangan penyabunan pada produk ini masih sesuai dengan SNI. Bilangan penyabunan menjadi indikasi kekeruhan pada produk, jika melebihi standart mutu SNI berarti menunjukkan bahwa produk tersebut keruh. Pada produk minyak ini masih sesuai standar Mutu SNI.

Adapun asam lemak bebas pada pengujian minyak kelapa ini adalah sebesar $0,17 \%$ sementara syarat mutu SNI minyak kelapa untuk asam lemak bebas adalah sebesar 0,2 \%, hal ini menunjukkan bahwa minyak ini masih memenuhi syarat SNI. Adapun asam lemak bebas pada minyak kelapa merupakan salah satu indikasi kerusakan pada minyak, semakin tinggi asam lemak bebasnya maka semakin tinggi pula peluang terjadinya kerusakan pada minyak.

Hasil pengujian tersebut disampaikan kepada mitra melalui sosialisasi. Tim menjelaskan hasil analisa kandungan kimia yang terdapat pada minyak kelapa. Setelah dilakukan sosialisasi, 
mitra dapat memahami dengan baik fungsi dari masing-masing kandungan kimia dalam minyak. Mitra juga dianggap telah mampu memproduksi minyak sesuai materi yang telah diajarkan. Kriteria keberhasilan ini didasarkan pada hasil kerja praktik mandiri yang dilakukan oleh mitra, yang memperlihatkan perbedaan kinerja saat pertama kali diajarkan. Praktik pembuatan dilakukan sebanyak empat kali, yang terdiri dari satu kali dilakukan secara bersama-sama (mitra dan tim) dan tiga kali dilakukan secara mandiri. Pada akhir sesi sosialisasi, tim menyampaikan agar mitra konsisten dalam pembuatan minyak. Konsisten yang dimaksud terkait dengan komposisi bahan yang digunakan. Komposisi bahan tersebut sesuai dengan anjuran yang telah diajarkan oleh tim.

\section{Desain Kemasan yang Menarik}

Kemasan memiliki fungsi yang penting untuk menarik konsumen. Kemasan juga meningkatkan nilai penjualan karena konsumen akan lebih tertarik membeli produk dengan tampilan kemasan yang menarik, selain itu informasi nilai gizi juga akan menjadi acuan konsumen untuk membeli. Desain kemasan dibuat oleh tim pengabdi kemudian dicetak dalam kertas stiker lalu ditempelkan di botol plastik kemasan. Proses penempelan dilakukan oleh tim dan mitra sehingga mereka juga terlibat langsung secara mandiri untuk mengetahui bagaimana proses pengemasan produk. Tahap ini dilakukan dengan tatap muka langsung kepada mitra, kegiatan ini dilakukan di rumah produksi IKM mitra. Tim pengabdi memberikan beberapa perubahan terhadap kemasan, dengan mengubah wadah yang awalnya menggunakan plastik, diganti dengan botol kemasan 330, 600, dan $1000 \mathrm{~mL}$. Desain stiker dan kemasan botol yang digunakan ditampilkan pada Gambar 4 dan 5.

Dibandingkan dengan kemasan sebelumnya, kemasan yang di desain oleh tim Politeknik Gorontalo lebih menarik, hal ini dilihat dari ketajaman warna, informasi label juga lebih lengkap ditambah karena adanya informasi gizi. Kemasan dan label merupakan salah satu faktor yang mambuat sesorang untuk memutuskan untuk membeli suatu produk, semakin menarik kemasan maka semakin tertarik konsumen untuk melihat dan memutuskan membeli. Hal ini di sampaikan dalam suatu penelitian yang menunjukkan bahwa konsumen membutuhkan waktu rata-rata tujuh detik ketika membuat keputusan pembelian (Maine 2014). Kemasan harus dapat menarik perhatian konsumen dalam waktu yang singkat, yaitu setengah detik untuk dikenali dan setengah detik kemudian untuk dicintai (Gobe 2003; Wang \& Chen 2007). Pada kemasan ini menunjukkan adanya perpaduan warna orange dan kuning menunjukkan warna minyak dan adanya tulisan minyak "Yinulo Bongo" menunjukkan bahasa daerah yang artinya minyak kelapa, ini menambah menarik desain kemasan dan informasi lengkap tentang kandungan gizi tertera pada kemasan (Gambar 6).

Pelatihan kemasan terdiri dari dua tahap yang pertama, tim mendesain stiker yang akan ditempelkan pada botol. Desain tersebut didasarkan pada hasil diskusi antara mitra dan tim. Setelah desain jadi, tim mengirimkan desain kepada mitra untuk ditanggapi. Butuh waktu tiga kali perbaikan untuk mendapatkan desain terbaik. Kedua, tim pengabdi membeli botol dan mencetak stiker. Pelatihan pada tahap ini hanya mencakup pada proses pemotongan stiker dengan gunting dan penempelan stiker pada botol. Hasil pelatihan menunjukkan bahwa proses tersebut dapat dilakukan oleh mitra dengan baik. Hasil kemasan ini, membuat mitra senang dan optimis produknya dapat bersaing dengan baik dipasaran. Karena jika mengevaluasi

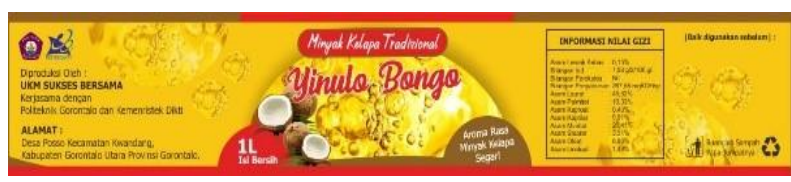

Gambar 4 Desain stiker untuk kemasan.

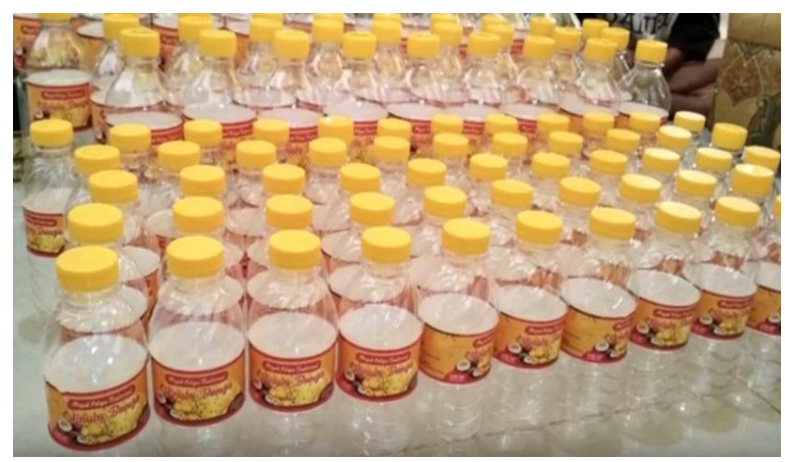

Gambar 5 Kemasan minyak kelapa.

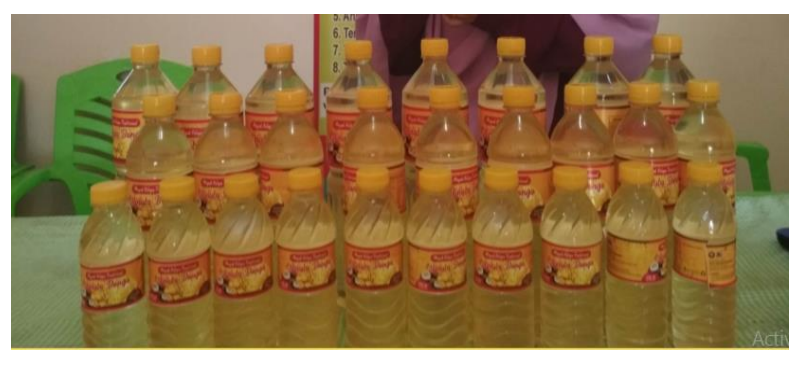

Gambar 6 Produk Minyak kelapa yang siap dipasarkan. 
selama ini Mitra IKM Sukses bersama menggunakan kemasan botol jeregen $5 \mathrm{~L}$ dengan stiker berwarna cokelat sehingga pemasaran khusus kepada tokoh-tokoh saja yang di jual dalam bentuk curah. Dengan lkemasan yang telah terbaru maka mitra IKM lebih bisa menjual dengan berbegai ukuran dan jangkauan pasar lebih luas serta bentuk kemasan lebih menarik.

\section{Manajemen Usaha dan Strategi Pemasaran}

Manajemen usaha adalah hal yang sangat penting dalam membangun suatu usaha, baik industri kecil menengah (IKM) dan usaha kecil menegah (UKM). Perbedaan antara IKM dan UKM hanya terletak pada produk yang dijual. IKM memproduksi produk sendiri dan dijual kepasaran, sedangkan UKM membeli produk dari pengusaha yang lebih besar dari usahanya dan menjualnya kembali untuk memperoleh keuntungan. Pemberian materi tentang manajemen usaha ini disajikan dalam bentuk diskusi langsung kepada pelaku usaha yang sudah berpengalaman dalam hal ini, kami selaku tim mengundang pelaku usaha dibidang pangan, yakni usaha teh daun sirsak. Pada tahap ini pemateri memaparkan tentang pengalamannya dalam merintis usaha yang dimilikinya dan berbagi kepada IKM Sukses Bersama bagaimana merancang produk, proses pembuatan produk yang berkualitas, proses pengemasan, teknik pemasaran sampai pada bagaimana mendapatkan pemasukan bahkan beliau memaparkan tentang cara mengurus sertifikasi produk seperti IRT, sampai kegiatan ini berlangsung pengurusan PIRT sudah pada tahapan mengikuti pelatihan dari dinas kesehatan, dan ini merupakan rangkaian mendapatkan IRT.

Pemasaran merupakan suatu usaha atau rencana strategis yang diarahkan oleh pelaku usaha untuk berinteraksi secara langsung kepada konsumen tentang produk yang mereka hasilkan untuk dipromosikan sehingga keuntungan melalui promosi. Saat ini teknik pemasaran sudah berkembang pesat, media sosial adalah alat komunikasi pemasaran paling murah dan efektif yang dapat dilakukan untuk menjual produk kepada konsumen. Dengan dasar ini maka tim pengabdi pun mengarahkan kepada IKM Mitra melakukan pemasaran melalui media sosial.

Kegiatan ini dilakukan di rumah produksi dan bentuknya adalah dengan diskusi dan praktik secara langsung tentang teknik pemasaran yang efektif. Pertama-tama tim mengarahkan membuat email yang diberi nama IKM Sukses Bersama kemudian membuat situs penjualan melalui facebook dan tokopedia sehingga IKM Sukses Bersama dapat menjadi penjual secara online agar produk ini tidak hanya untuk pemasaran sekitar Gorontalo tetapi melalui pemasaran online keseluruh wilayah Indonesia. Setiap akun yang digunakan, dibuat dan dikembangkan oleh tim pengabdi. Penggunaan nama pada masingmasing akun sosial media disesuaikan dengan nama produk, yakni "Yinulo Bongo". Operator yang bertugas dalam mengoperasikan akun-akun tersebut adalah anggota IKM. Hasil dari pelatihan ini, pihak IKM sudah dapat mengoperasikan media sosial dan situs jual beli online dengan baik. Dalam pelatihan tersebut tim hanya tidak melibatkan pihak lain, karena sosial media yang digunakan sudah umum dilakukan dan mudah untuk dibuat dan dikembangkan. Dalam pengaplikasian, penerapan sistem online tidak mendapatkan masalah, karena sebagian besar anggota mitra sudah terbiasa menggunakan smartphone dan media sosial. Proses pelatihan manajemen usaha ditampilkan pada Gambar 7. Setelah dilaksanakan kegiatan ini dengan pemberian pelatihan kepada mitra IKM Sukses Bersama maka menambah pendapatan dari pihak mitra IKM, hal ini diungkapkan oleh Mitra bahwa mereka dipercaya sebagai penyedia minyak goreng tradisional untuk program bantuan pemerintah non subsidi (BPNT) sebanyak $10.000 \mathrm{~L} /$ bulan.

\section{SIMPULAN}

Kegiatan pengabdian pengembangan usaha minyak kelapa tradisional membawa dampak positif berupa penambahan pengetahuan, skill, omset, dan pendapatan bagi pihak IKM. Kegiatan alih teknologi dan pendampingan selama penerapan teknologi mampu meningkatkan Iptek pihak IKM sehingga produk minyak kelapa yang dihasilkan sesuai Standar Nasional Indonesia

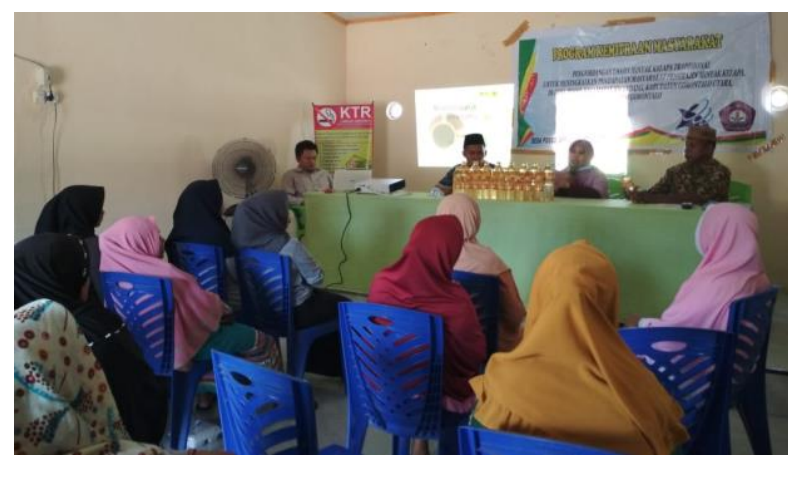

Gambar 7 Pelatihan manajemen usaha dan pemasaran. 
minyak kelapa SNI 7381:2008. Penyediaan mesin pengupas sabut kelapa mampu mengefisienkan waktu pengupasan sabut kelapa sehingga produksi setiap hari meningkat dari angka $60 \mathrm{~L}$ menjadi $150 \mathrm{~L}$ atau setara 200 botol. Hal ini berarti bahwa kapasitas produksi meningkat 2 kali lipat dibandingkan sebelum pendampingan. Pelatihan manajemen usaha dan pemasaran setelah diterapkan secara signifikan mampu meningkatkan penjualan dan keuntungan IKM mitra. Secara keseluruhan kegiatan telah mampu meningkatkan kapasitas dan mutu produk IKM yang dihasilkan serta membantu IKM untuk berkembang dan meningkatkan pendapatannya. Hal ini dibuktikan dengan 1) Kapasitas pengupasan sabut kelapa dengan menggunakan mesin yang tadinya hanya 1.100 butir/hari dengan alat tradisional menjadi 2.057 butir/hari; 2) Jumlah produksi minyak kelapa yang meningkat; 3) Hasil praktik yang dapat dilakukan oleh mitra dengan indikator hasil pembuatan dan tahapan yang sesuai materi yang diajarkan; dan 4) hasil uji laboratorium terhadap produk yang sesuai dengan standar SNI.

\section{UCAPAN TERIMA KASIH}

Ucapan terima kasih penulis berikan kepada Direktorat Riset dan Pengabdian Masyarakat, Direktorat Jenderal Penguatan Riset dan Pengembangan Kementerian Riset, Teknologi, dan Pendidikan Tinggi, yang telah membiayai pengabdian ini sesuai dengan Kontrak Pengabdian Tahun Anggaran 2019.

\section{DAFTAR PUSTAKA}

Andaka G, Karomatul F. 2017. Pengambilan Minyak Kelapa dengan Menggunakan Enzim Papain. Dalam: Prosiding Seminar Nasional XII "Rekayasa Teknologi Industri dan Informasi 2017 Sekolah Tinggi Teknologi Nasional Yogyakarta. Yogyakarta (ID): Sekolah Tinggi Teknologi Nasional Yogyakarta.

Alridho A, Syawaldi, Irwan A. 2018. Perencanaan Mesin Pengupas Sabut Kelapa dengan Menggunakan Mata Pisau Miring (Planning of
Coconut Fabric Machines Using Sling Knife Eyes). Journal Renewable Energy \& Mechanics (REM). 01(02): 23-39. https://doi.org/ 10.25299/rem.2018.vol1.no02.1252

BPS badan Pusat Statistik. 2016. Provinsi Gorontalo dalam Angka Tahun 2016. [internet]. [Diakses pada: 1 Maret 2019]. Tersedia pada: www.gorontalo.bps.go.id.

[BSN] Badan Standardisasi Nasional. 1992. SNI 01-2901-1992, Minyak kelapa sawit. [Internet]. [Diakses pada Januari 2020]. Tersedia pada http://sispk.bsn.go.id/ SNI/DetailSNI/3270

[BSN] Badan Standardisasi Nasional. 2008. SNI 7381:2008, Minyak Kelapa Virgin (VCO). Jakarta (ID): Badan Standardisasi Nasional.

Gobe M. 2003. Emotional branding. Jakarta (ID): Erlangga.

Hawin R. 2010. Pengaruh Suhu Air Perasan Kelapa dan Lama Pemanasan pada Microwave dalam Pembuatan Minyak Kelapa Kasar Terhadap Rendemen dan Mutu Minyak. [Tesis]. Malang (ID): Universitas Brawijaya.

Maine S. 2014. How product packaging affects buying decisions.[Internet]. Diakses pada: Januari 2020. Tersedia pada: http://www. creativeblog.com/graphic-design/howproduct-packaging-affets-buying-decisions91412911

Raharja S, Dwiyuni M. Kajian Sifat Fisiko Kimia Ekstrak Minyak Kelapa Murni (Virgin Coconut Oil, Vco) yang Dibuat dengan Metode Pembekuan Krim Santan. Jurnal Teknologi Industri Pertanian. 18(2): 71-78.

Soeka YS, Sulistyo J, Naiola E. 2008. Analisis Biokimia Minyak Kelapa Hasil Ekstraksi secara Fermentasi. Biodiversitas. 9(2): 91-95. https://doi.org/10.13057/biodiv/d090203

Wang RWY, Chen WC. 2007. The Study on Packaging Illustration Affect On Buying Emotion. In: Proceeding. International Association of Societies andDesign Research, Hong Kong Polytech University. 